\title{
Breaking the mould of vanity publishing
}

Every issue of arq published to date has contained at least one paper on a building, series of buildings or planning project. All have been generously illustrated and written at a depth and length which the professional press can no longer sustain. But, on closer inspection, all is not well.

For example, in the first of two papers in the design section of this issue, Peter Blundell Jones' provides a penetrating review of Rudolphe Luscher's skilful and elegant extensions to an undistinguished group of school buildings. However, the many fine photographs which accompany Blundell Jones' critique are notable for the fact that every single one depicts an uninhabited space. There's nothing new in this: both author and arq are caught in a system of architectural photography in which space is often shown uninhabited.

In the second paper, Frank Duffy describes how architecture has served as a catalyst in the 'change management' of a major international airline. It's an intriguing account with many hopeful pointers for architecture and architects. Peter Cook's photographs are well populated but Duffy himself makes it clear that further research is needed to evaluate the effectiveness of Waterside in meeting British Airways' corporate objectives and in raising productivity.

But will even an enlightened client like BA permit any post-occupancy evaluation of the building, its fabric and environmental systems? And, if it does, will the airline, its insurers and its lawyers allow it to be published? It is important that they do so for, in the long run, research which covers a broad spectrum of inter-related factors and is focused on buildings of architectural significance is truly valuable for society at large.

For too long, architectural publishing has illustrated and reviewed largely unoccupied and untested buildings. Photographers and critics have had to make the best of a situation in which they are really only welcome before a building becomes fully operational. They, at least, can be forgiven - which is more than can be said of editors fighting to be the first to publish this or that new building.

This mould of what might be described as architectural vanity publishing must be broken. It damages our image and reputation as a profession by contradicting our stated goals. It isn't vanity. It's counterproductive. 


\section{architectural}

research

\section{Subscribe now and save 20\% quarterly}
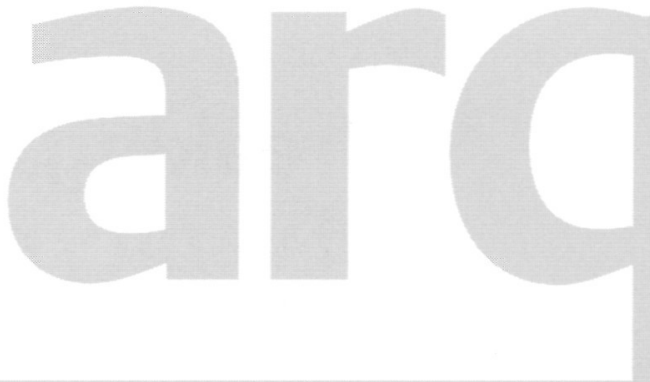

This ground-breaking quarterly publication, to be published by Cambridge University

Press from 1999, aims to act as an

international forum for practitioners and

academics by publishing cutting-edge

research covering all aspects of architectural

endeavour. Fully illustrated throughout,

arq includes sections on design, history,

theory, environmental design, construction,

information technology, and practice.

New features for 1999 include an updated

and comprehensive reviews section,

and investigation which will report on

developments in the field, including new

building types, methods and products.

A further development will be the arq

directory - a listing of specialist research and

consultancy with an online, cumulative

version which aims to provide a lasting and

invaluable resource for all. arq presents

information in a way that is designed to be

accessible to all and is essential reading for

practitioners in industry and consultancy

as well as for academic researchers.

It provides an outlet for all those who

wish to disseminate their work to an

international audience.
Please enter my subscription to

arq: architectural research quarterly, volume 3, 1999

$£ 76$ (normally $€ 95$ ) institutions print only

E22 (normally $E_{22} 8$ ) students

£44 (normally $£_{55}$ ) individuals print only

Eu residents only. VAT may be payable at your local rate if not registered.

OurVAT registration number: GB 214141614

If registered, your VAT registration no:

Total subscription payment $E$

Eu residents only, if not registered add VAT at appropriate rate

Total E

Name

Address

\section{Payment enclosed}

Cheque in sterling (payable to Cambridge University Press)

Bank Draft

Post Office Giro (A/C no 5716055 GB Bootle - please send advice of payment)

Credit Card - VISA | MasterCard | American Express (delete where applicable)

Card no

Expiry date

Signature

Send your order to: Journals Customer Services,

Cambridge University Press, Edinburgh Building,

Shaftesbury Road, Cambridge, CB2 2RU

$T+44(0) 1223326070$

F $+44(0) 1223315052$

F journals_subscriptions@cup.cam.ac.uk 